\title{
Visible and near-infrared spectroscopy detects queen honey bee insemination*
}

\author{
Thomas C. WeBster ${ }^{1}$, Floyd E. Dowell ${ }^{2}$, Elizabeth B. MAGHIRANG ${ }^{2}$, \\ Etta M. THACKER ${ }^{3}$
}

\footnotetext{
${ }^{1}$ Land Grant Program, Atwood Research Facility, Kentucky State University, Frankfort KY 40601, USA

${ }^{2}$ USDA-ARS Grain Marketing and Production Research Center, 1515 College Ave. Manhattan, KS 66502, USA

${ }^{3}$ Land Grant Program, Atwood Research Facility, Kentucky State University, Frankfort, KY 40601, USA
}

Received 27 August 2008 - Revised 4 February 2009 - Accepted 10 February 2009

\begin{abstract}
The abdomens of honey bee queens and semen from drone bees were analyzed by visible and near-infrared spectroscopy. Mated honey bee queens could be distinguished from virgin queens by their absorption spectra with $100 \%$ accuracy. Spectra of semen showed that classifications of queens were likely influenced by the presence or absence of semen in the queen spermathecae. However, physiological or morphological changes that occur in the queens after mating probably influenced the classifications also.
\end{abstract}

Apis mellifera / drone semen / mating / queen bee / spectroscopy

\section{INTRODUCTION}

The insemination of queen honey bees is difficult to determine because the semen stored in her spermatheca cannot be observed directly without dissection. While the queen's egg laying behavior is an indication of whether she has mated, a rapid and non-destructive method for determining the queen's mating success is not available. Problems with queen and drone fertility and viability may be related to widespread honey bee colony mortality in North America, Europe, and other regions (Pettis et al., 1991; Rinderer et al., 1999; Collins and Pettis, 2001; Stokstad, 2007). A rapid, non-invasive method for assessing these factors would be useful in studies of affected bee colonies.

Visible and near-infrared (VIS-NIR) spectroscopy is a fast and non-destructive technique that has been used to determine many

Corresponding author: T.C. Webster,

Thomas.webster@kysu.edu

* Manuscript editor: Stefan Fuchs different insect characteristics. It measures absorbance by chemical functional groups. This technique has successfully differentiated insect species (Dowell et al., 1999; Cole et al., 2003; Aldrich et al., 2007; Jia et al., 2007), determined sex (Dowell et al., 2005) and age (Perez-Mendoza et al., 2002), detected insects inside grain kernels (Maghirang et al., 2003), and detected parasitized insects (Dowell et al., 2000). Wallis (2007) suggested that VIS-NIR spectroscopy may be useful for predicting various attributes of bees and that it could be useful for apiculture. The objective of this study was to evaluate the feasibility of VIS-NIR spectroscopy for distinguishing virgin queens from mated queens.

\section{MATERIALS AND METHODS}

\subsection{VIS-NIR spectroscopy}

Queen bees were positioned on a $5 \mathrm{~cm}$ diameter Spectralon diffuse reflectance plate (Labsphere, 
North Sutton, NH) and scanned using a $6.3 \mathrm{~mm}$ diameter bifurcated probe oriented vertically $6.8 \mathrm{~mm}$ above the Spectralon. This probe had 78 fibers used for illumination, and 78 fibers for reflectance. All fibers were randomized in the probe tip. A Mikropack HL-2000 halogen light source (Micropack Ostfildern, Germany) was used to illuminate the bee. Visible and near infrared (350$2500 \mathrm{~nm}$ ) reflected energy was measured using a QualitySpec Pro spectrometer (ASD Inc, Boulder, $\mathrm{CO}$ ). A baseline was measured using a $2.5 \mathrm{~cm}$ diameter Spectralon plate. The spectrometer utilizes a silicon sensor ( $\sim 350-950 \mathrm{~nm})$, an indium-galliumarsenide (InGaAs) sensor ( $\sim 950-1750 \mathrm{~nm})$, and a cooled InGaAs sensor ( 1750-2500 nm).

For scanning bee semen, a $2 \mathrm{~mm}$ bifurcated probe that had about 50 illumination fibers and 5 reflectance fibers was used. The probe was positioned directly above the semen that was held in a glass capillary tube and positioned on the Spectralon.

The instrument automatically collected 20 spectra from each specimen and then stored an averaged spectrum. The procedure took less than 1 minute per specimen and included positioning the insect and collecting the spectra. ASD software RS ${ }^{3}$ (Version 3.1) was used to collect spectra. Spectra were then converted using ASD ViewSpecPro to a format that could be imported into GRAMS (Thermo Galactic, Salem, NH, USA).

\subsection{Queen bees and drone semen}

Fifty two mated queens and 52 virgin queens were purchased from Wilbanks Apiaries, Claxton, GA and shipped in one package by overnight mail to the USDA-ARS Grain Marketing and Production Research Center at Manhattan KS. Each queen was shipped in an individual wooden queen cage with approximately five worker bees and a sugar paste for food, according to standard practice in the USA. All mated queen bees were naturally mated and between 14 and 21 days old. Their mating success was determined by the development of worker brood from their eggs. Virgin queens were also 14 to 21 days old. They had been caged since they emerged from their cells, and hence were unable to mate.

The day the queens arrived they were individually immobilized with $\mathrm{CO}_{2}$ and placed ventral side up on the Spectralon plate. The beam was directed through the posterior portion of the abdomen, which contains the spermatheca (Dade, 1994). The immobilization and scanning procedure took less than one minute for each queen.
Bee semen was obtained from Glenn Apiaries (Fallbrook, CA) in glass capillary tubes sealed with Parafilm (American National Can, Greenwich, CT) on each end. Seventy $\mu \mathrm{L}$ of semen was collected from 75 Italian drones, and $70 \mu \mathrm{L}$ of semen was collected from 79 Carniolan drones. Italian and Carniolan semen samples were placed in separate tubes. The semen was collected March 3, 2008, and shipped by overnight mail to Manhattan KS, where the samples were scanned the next day. The tubes were scanned by placing the fiber probe directly above the semen. An empty tube was scanned to determine the effect of the tube on the spectra.

\subsection{Statistical analyses}

Spectral data were analyzed using partial least squares regression (PLS) (Martens and Naes, 1989) using GRAMS PLS/IQ software. Comparisons were made using PLS by assigning a value of 1 or 2 for each pairwise combination of mated versus virgin queens.

The wavelengths important in classifying the species of interest were determined by examining the PLS regression coefficients and difference spectra. The accuracy of the classification models was determined using weighted correct classification, coefficient of determination $\left(r^{2}\right)$ indicating the closeness of fit between the spectra and reference data, standard error of cross validation (SECV) using a one-sample-out procedure (Williams, 2001), and by predicting validation sets.

\section{RESULTS}

\subsection{VIS-NIR spectra}

The spectra were very noisy below $450 \mathrm{~nm}$ due to low energy from the lamp at those wavelengths, and also very noisy above $2150 \mathrm{~nm}$ due to poor sensor sensitivity at the higher wavelengths. Thus all analyses included only the 450-2150 $\mathrm{nm}$ region.

\subsection{Queen bees and drone semen}

Virgin queens were readily distinguished from mated queens by analyzing their spectra. Figure 1 shows mean spectra of the virgin and mated queen bees. The individual spectra had 


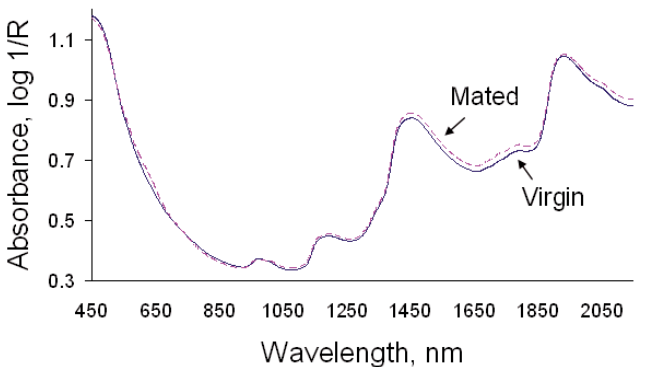

Figure 1. Absorbance spectra (log 1/reflectance) of virgin and mated queen bees. Each plot represents the mean spectrum of 52 queen bees.

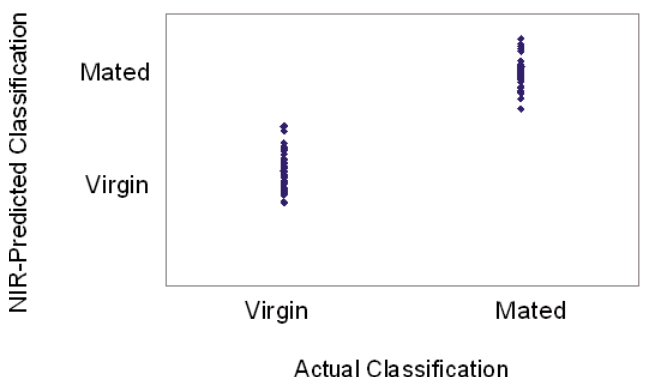

Figure 2. Accuracy of classifying queen bees as virgin or mated from their visible and near infrared spectra when using a partial least squares regression model with six factors.

a standard deviation of about 0.05 absorbance units around the mean (data not shown), and thus overlap between the virgin and mated spectra existed.

Although the mean spectra look very similar, differences between them indicate where functional groups absorb differently for the virgin and mated queens. When using a PLS regression with eight factors, all mated and virgin queens could be differentiated with $100 \%$ accuracy (Fig. 2).

The PLS regression coefficients and the difference between the mated and virgin spectra (Fig. 3) indicate what wavelengths are used for classifications and what functional groups may be contributing to classifications. The absolute values of the regression coefficients are largest for the wavelengths that contribute most to the prediction equation. There are distinct absorption peaks throughout the VIS and NIR regions that indicate differences in the virgin and mated queens, allowing this technique to classify them appropriately. The large positive peak at $545 \mathrm{~nm}$ and negative peak at $643 \mathrm{~nm}$ indicate a difference between the spectra of mated and virgin queens. However, if this visible region is excluded from the PLS analysis, similar classification results are still obtained. The peaks around 1700, 1150, 930, and $780 \mathrm{~nm}$ correspond to C-H 1st, 2nd, 3rd, and 4th overtones, respectively (Shenk et al., 2001). The peaks around 1520 and $780 \mathrm{~nm}$ correspond to $\mathrm{RNH}_{2} 1$ st and 2nd overtones, respectively. The peaks around 1370 and $930 \mathrm{~nm}$ correspond to ROH 1 st and 2nd overtones, respectively. The difference spectra calculated by subtracting the average of the virgin spectra from the average of the mated spectra show peaks that correspond to the regression coefficients with the exception of the peak around $1000 \mathrm{~nm}$. This peak does not correspond to a meaningful functional group and is an artifact of a cross-over point where the silicon and InGaAs sensors merge.

To further test our ability to distinguish between mated and virgin queens we randomly selected 42 mated and 42 virgins and created a calibration from these 84 bees. The regression coefficients (not shown) for the calibration equation when using six factors were very similar to those shown in Figure 3. We then predicted whether the remaining 20 queens were mated or virgins. When predicting this validation set, all queens were correctly predicted as mated or virgins. Thus, our models correctly predicted all queens as virgin or mated when using either a cross validation technique or when predicting a validation set.

Figure 3 also shows the absorbance spectrum of drone bee semen. The semen spectra from the Italian and Carniolan bees were essentially identical. A spectrum of the empty glass tube showed that it had no influence on the semen spectrum. A small peak in the semen spectrum at about $630 \mathrm{~nm}$ corresponds to peaks in the difference spectrum and the regression coefficients at the same wavelength (left box). Similarly, peaks in the semen spectrum, difference spectrum and regression coefficients coincide at about $1400 \mathrm{~nm}$ (right box). This suggests that the model used to differentiate between virgin and mated bees is 


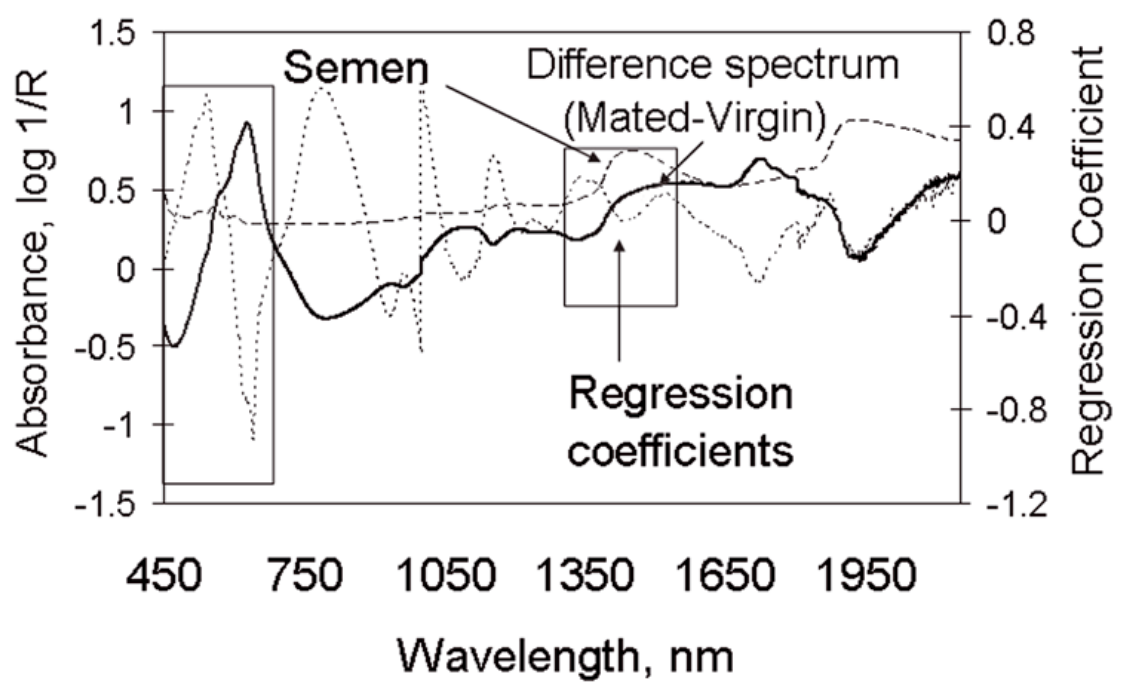

Figure 3. Regression coefficients and difference spectrum for classifying virgin or mated queen bees, and drone semen spectrum. The regression coefficients multiplied by the bee spectra determine whether the bees are classed as virgin or mated. Thus, wavelengths with larger positive or negative regression coefficients indicate where major differences in mated and virgin bees exist. The difference spectrum is the mean mated queen spectrum minus the mean virgin queen spectrum from Figure 1.

partly due to the absorbance spectrum of semen. However, most semen peaks do not coincide with peaks in the difference spectrum and regression coefficients.

\section{CONCLUSIONS}

By the use of spectroscopy, mated and virgin honey bee queens may be distinguished very quickly and without affecting the queens, except that they must be briefly removed from their hives and immobilized by $\mathrm{CO}_{2}$. While $\mathrm{CO}_{2}$ treatment has long-term effects on queen physiology (Laidlaw and Page, 1997; Mackensen, 1947), it could not have affected the spectra we obtained. Each queen was scanned immediately after treatment.

The difference in mated and virgin queen spectra appears to be due partly to the presence of semen in the spermathecae of the mated queens. However it is likely that other queen bee tissues contribute to this difference. Queen physiology changes significantly after mating (Hrassnigg et al., 2003).
The functional groups associated with peaks in Figure 3 have been associated also with human semen (Deepinder et al., 2007). Possibly these relate to chemical similarities in drone and human semen.

\section{ACKNOWLEDGEMENTS}

We thank Steve and Becky Tipton for moving their hives to the project site and allowing us to use them. Joli Winer and Sharon Dobesh kindly coordinated the hive movement, and Sharon Dobesh helped with sample analysis. The Kansas State Beekeepers Association assisted with travel expenses. This project was supported by grants from USDA/CSREES to Kentucky State University under agreements number KYX-10-02-36P and KYX10-07-41P to TCW.

La spectroscopie visible et la spectrométrie IR proche détectent l'insémination des reines d'abeilles.

Apis mellifera / accouplement / reine d'abeille / sperme / spectroscopie 
Zusammenfassung - Durch VIS-NIRSpektroskopie kann die Besamung der Honigbienenkönigin festgestellt werden. Im Allgemeinen können die inneren Organe der Honigbienen nicht untersucht werden, ohne die Bienen zuvor zu töten. Eine schnelle und nicht invasive Methode zum Nachweis von Sperma in der Spermatheka der Bienenkönigin wäre aber äußerst nützlich. Die VIS-NIR-Spektroskopie (parallele Spektroskopie im sichtbaren Wellenlängenbereich und im Nahen Infrarot) wurde bereits erfolgreich bei anderen Untersuchungen von Insektengeweben eingesetzt; hier wurde sie dazu benutzt, unbegattete Königinnen, begattete Königinnen und das zugehörige Drohnensperma zu identifizieren. Wir untersuchten 52 begattete und 52 unbegattete Königinnen, indem wir den Strahl des Spektrometers auf den Abschnitt des Königinnenabdomens richteten, in dem sich die Spermatheka befindet. Dabei konnten begattete von unbegatteten Königinnen zu $100 \%$ unterschieden werden (Abb. 1 und Abb. 2). Die Unterschiede in den Spektren könnten durch das Sperma in der Spermatheka der begatteten Königinnen hervorgerufen worden sein (Abb. 3). Allerdings scheinen auch physiologische und morphologische Veränderungen, die bei der Königin nach der Paarung auftreten, eine wichtige Rolle bei den Unterschieden zwischen den Spektren zu spielen.

\section{Apis mellifera / Drohnensperma / Paarung / Kö- nigin / Spektroskopie}

\section{REFERENCES}

Aldrich B.T., Maghirang E.B., Dowell F.E., Kambhampati S. (2007) Identification of termite species and subspecies of the genus Zootermopsis using near-infrared reflectance spectroscopy, J. Insect Sci. 7, 18.

Cole T.J., Ram M.S., Dowell F.E., Omwega C.O., Overholt W.A., Ramaswamy S.B. (2003) Nearinfrared spectroscopic method to identify Cotesia flavipes and Cotesia sesamiae (Hymenoptera: Braconidae), Ann. Entomol. Soc. Am. 96, 865869.

Collins A.M., Pettis J.S. (2001) Effect of Varroa on semen quality, Am. Bee J. 141, 590-593.

Dade H.H. (1994) Anatomy and dissection of the honey bee, International Bee Research Association, Cardiff, UK.

Deepinder F., Chowdary H.T., Agarwal A. (2007) Role of metabolomic analysis of biomarkers in the management of male infertility, Expert Rev. Mol. Diagn. 7, 351-356.

Dowell F.E., Broce A.B., Xie F., Throne J.E., Baker J.E. (2000) Detection of parasitized fly puparia using near-infrared spectroscopy, J. Near Infrared Spectrosc. 8, 259-265.
Dowell F.E., Parker A.G., Benedict M.Q., Robinson A.S., Broce A.B., Wirtz R.A. (2005) Sex separation of tsetse fly pupae using near-infrared spectroscopy, Bull. Entomol. Res. 95, 249-257.

Dowell F.E., Throne J.E., Wang D., Baker J.E. (1999) Identifying stored grain insects using near-infrared spectroscopy, J. Econ. Entomol. 92, 165-169.

Hrassnigg N., Leonhard B., Crailsheim K. (2003) Free amino acids in the haemolymph of honey bee queens (Apis mellifera L.), Amino Acids 24, 205212.

Jia F., Maghirang E., Dowell F., Abel C., Ramaswamy S. (2007) Differentiating tobacco budworm and corn earworm using near-infrared spectroscopy, J. Econ. Entomol. 100, 759-764.

Laidlaw H.H., Jr., Page R.E. (1997) Queen rearing and queen breeding, Wicwas Press, Cheshire, CT.

Mackensen O. (1947) The effect of carbon dioxide on initial oviposition of artificially inseminated and virgin queens, J. Econ. Entomol. 40, 344-349.

Maghirang E.B., Dowell F.E., Baker J.E., Throne J. E. (2003) Automated detection of single wheat kernels containing live or dead insects using nearinfrared reflectance spectroscopy, T. ASAE 46, $1277-1282$.

Martens H., Naes T. (1989) Multivariate calibrations, John Wiley \& Sons, Chichester, UK.

Perez-Mendoza J., Dowell F.E., Broce A.B., Wirtz R.A., Xie F., Fabrick J., Throne J.E., Baker, J.E. (2002) Chronological age-grading of house flies by using near-infrared spectroscopy, J. Med. Entomol. 39, 499-508.

Pettis J.S., Wilson W.T., Shimanuki H., Teel P.D. (1991) Fluvalinate treatment of queen and worker honeybees (Apis mellifera L.) and effects on subsequent mortality, queen acceptance and supersedure, Apidologie 22, 1-7.

Rinderer T.E., De Guzman L.I., Lancaster V.A., Delatte G.T., Stelzer J.A. (1999) Varroa in the mating yard: I. The effects of Varroa jacobsoni and Apistan on drone honey bees, Am. Bee J. 139, 134-139.

Shenk J.S., Workman J.J. Jr., Westerhaus M.O. (2001) Application of NIR spectroscopy to agricultural products, in: Burns D., Ciurczak E. (Eds.), Handbook of Near-Infrared Analysis, Marcel Dekker Inc, New York, NY, pp. 419-474.

Stokstad E. (2007) The case of the empty hives, Science 316, 970-972.

Wallis I. (2007) Predicting the productivity of honeybees from the nutritional value of pollen, in: Honeybee Research Report 2007, RIRDC Publication No. 07/009, Australian Government Rural Industries Research and Development Corporation: Kingston, ACT, pp. 18-19.

Williams P.C. (2001) Implementation of near-infrared reflectance technology, in: Williams P., Norris K. (Eds.), Near-infrared Technology in the Agricultural and Food Industries, Am. Assoc. Cereal Chem. Inc., St. Paul, MN, pp. 145-169. 